\title{
Bee Venom Acupuncture for Shoulder Pain: A Systematic Review and Meta-analysis of Randomized Controlled Trials
}

\author{
Lei Shen ${ }^{1+}$, Jong Ha Lee ${ }^{2 \dagger}$, Jong Cheon Joo', Soo Jung Park ${ }^{3 *}$, Yung Sun Song ${ }^{4 *}$ \\ 1 Department of Constitutional Medicine, College of Korean Medicine, Wonkwang University, Iksan 54538, Republic of Korea \\ 2 Department of Korean Medicine Graduate School of Wonkwang University, Iksan 54538, Republic of Korea \\ ${ }^{3}$ Department of Sasang Constitutional Medicine, College of Korean Medicine, Woosuk University, Jeonju 55338, Republic of Korea \\ ${ }_{4}^{4}$ Department of Rehabilitation Medicine, College of Korean Medicine, Wonkwang University, Iksan 54538, Korea
}

\section{Key Words}

bee venom, meta-analysis, pharmacopuncture, shoulder pain, systematic review

\section{Abstract}

Objectives: Our review aimed to summarize and evaluate evidence on the effectiveness of bee venom acupuncture (BVA) in the treatment of shoulder pain.

Methods: Randomized controlled trials (RCTs) evaluating the effectiveness of BVA on shoulder pain were searched up to October 2019 in 11 electronic databases (Medline, Embase, CENTRAL, CiNii, CNKI, VIP, Wanfang, Kmbase, NDSL, RISS, OASIS). The methodological quality of the included RCTs were evaluated using Cochrane Risk of Bias tool and a meta-analysis was performed.

Results: Seven studies were included in the review, and four studies were included in the meta-analysis. Comparing BVA plus conventional therapy (CT) with saline injection plus CT, it showed an effect in favor of BVA plus CT in visual analog scale (VAS) and pain rating scale (PRS) ( $\mathrm{p}=0.02, \mathrm{p}=0.009$, respectively). Comparing BVA plus physiotherapy (PT) with saline injection plus PT, it showed that there was no significant difference in VAS and verbal rating scale (VRS) between the two groups.
Received: Jan 23, 2020 Reviewed: Feb 29, 2020 Accepted: May 18, 2020

(c) This is an Open-Access article distributed under the terms of the Creative Commons Attribution Non-Commercial License (http://creativecommons.org/licenses/by-nc/4.0/) which permits unrestricted noncommercial use, distribution, and reproduction in any medium, provided the original work is properly cited.

$\otimes$ This paper meets the requirements of KS X ISO 9706, ISO 9706-1994 and ANSI/NISO Z39.48-1992 (Permanence of Paper).
Conclusion: This systematic review and meta-analysis suggest that BVA could be beneficial as an adjuvant treatment for shoulder pain.

\section{Introduction}

Bee venom (BV) therapy has been used since ancient times. Bee venom acupuncture (BVA) is a treatment that involves injecting purified and diluted BV into acupoints [1]. In some Asian countries, including Korea and China, BVA is used to treat inflammatory diseases and cancers and reduce pain $[2,3]$. In particular, BVA has been used to treat a variety of painful conditions in a practical approach. BV contains many enzymes, peptides, and amines. Among these components, adolapin has anti-inflammatory and analgetic properties, and melittin also regulates the inflammatory response by inhibiting the DNA-binding activity of NF-kB $[4,5]$.

Shoulder pain is the most common symptom of musculoskeletal disorders, accounting for approximately $16 \%$ of all complaints [6]. A considerable number of patients $(41 \%)$ with new-onset shoulder pain show persistent or recurrent symptoms 12 months after presenting to their general practitioner [7]. Regardless of the cause of the shoulder pain, there is no universally effective treatment. In addition, most treatments are accompanied by varying degrees of side effects. Thus, finding an effective and safe complementary and alternative therapy is necessary.

There has been a systematic review and meta-analysis of randomized control trials (RCTs) to assess

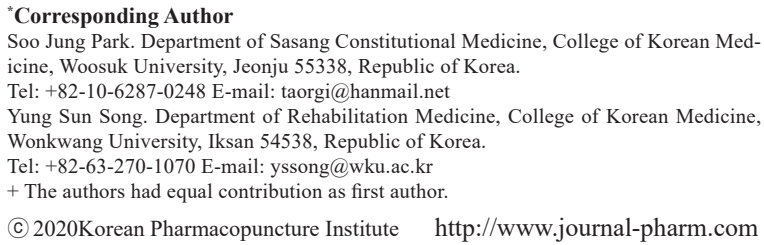

(C) 2020Korean Pharmacopuncture Institute http://www.journal-pharm.com 
the efficacy of BVA in reducing shoulder pain. Lim et al. [8] reviewed and meta-analyzed the effectiveness of BVA in alleviating post-stroke shoulder pain, but this review was limited to the shoulder pain after the occurrence of a stroke. Also, Lee et al. [9] reviewed the efficacy of BVA for various musculoskeletal pain, and suggested the evidence for the effectiveness of BVA in musculoskeletal pain management. However, this review needs to be updated.

Although there have been several clinical studies and few reviews of the effectiveness of BVA, there has been relatively little evidence evaluating BVA efficacy in the treatment of shoulder pain caused by various causes. We aimed to summarize on the effectiveness of BVA to treat shoulder pain.

\section{Materials and Methods}

\subsection{Data sources}

The search for relevant literature was conducted in the following 11 electronic databases from their inception to October 2019: Medline (PubMed), Excerpta Medica dataBASE (Embase), Cochrane Central Register of Controlled Trials (CENTRAL), Scholarly and Academic Information Navigator (CiNii), Chinese medical databases (China National Knowledge Infrastructure, Wanfang, and Journal integration platform), and Korean medical databases (Kmbase, National Discovery for Science Leaders, Research Information Sharing Service, and Oriental Medicine Advanced Searching Integrated System). The references in all located articles were manually searched for further relevant articles. We also searched the grey literature of theses, dissertations, letters, government documents, research reports, conference proceedings, and abstracts to avoid publication bias.

\subsection{Search strategy}

The keywords searched were: ["bee venoms" OR apitoxin OR apitherapy OR apipuncture OR "bee venom therapy" OR "bee venom acupuncture" OR "bee sting" OR "wasp venom"] AND ["shoulder pain" OR bursitis OR "shoulder impingement syndrome" OR "rotator cuff" OR "adhesive capsulitis" OR tendinitis OR tendonitis OR "frozen shoulder" OR shoulder*]. Searches were conducted in Korean, English, and Chinese. We adjusted search strategies for each of the databases. No restrictions were imposed on language, publication type or date. The detailed search strategies were described in the Appendix 1 .

\subsection{Eligibility criteria}

(1) Types of studies: The studies were restricted to RCTs that compared the efficacy of bee venom treatment with a control group, either placebo treatment or no treatment, in decreasing shoulder pain. Other study designs such as in vivo, in vitro, case reports, case series, conference papers, editorials, abstracts, retrospective studies, and cross-over designs were excluded. In addition, non-randomized and quasi-randomized trials were excluded. (2) Types of par- ticipants: Participants were patients with shoulder pain caused by musculoskeletal disorders. No restrictions were placed on age, sex, ethnicity, degree of pain, or disease duration. (3) Types of interventions: Bee venom therapy for shoulder pain caused by musculoskeletal disorders was considered an intervention. Interventions combined with other treatments were also included. There were no restrictions on frequency, bee venom dosage, and treatment duration. Bee venom was injected into the acupoints of the patients using a syringe. Live bee stings were excluded. The comparisons in this meta-analysis included placebo treatment, such as normal saline injection, acupuncture, or conventional therapy (CT). (4) Outcome measures: The primary outcome measure was the improvement in shoulder pain as a result of bee venom therapy in RCTs. In this review, the scales that assessed shoulder pain were the visual analog scale (VAS), pain rating scale (PRS) [10], verbal rating scale (VRS) [11]. Secondary outcome measures included the shoulder pain and disability index (SPADI) [12], and adverse events.

\subsection{Study selection and data extraction}

The study selection was conducted independently by two reviewers, (JHL and LS). Duplicate studies were excluded by comparing the title, author, and publication date.

The two reviewers extracted the data according to the databases based on the selection criteria. If two reviewers had disagreements, they were resolved by discussion. Also, If the title, author, and published date of the study were same, it was judged as a duplicate study. The data of the included studies were arranged according to the general characteristics (author, year of publication), patients' conditions (type of disease, mean age), sample size, interventions for experimental and control group, period of treatment, acupoint, outcome measures, summary of results, and adverse events.

\subsection{Quality assessment}

Two investigators assessed methodological quality by using the Risk of Bias (RoB) tool [13], which was developed by Cochrane. Each study was assessed for random sequence generation, allocation concealment, blinding of participants and personnel, blinding of outcome assessment, incomplete outcome data, selective outcome reporting, and other biases. Disagreements were resolved by discussion between the two reviewers.

\subsection{Data analysis}

The meta-analysis and statistical analysis were performed using the RevMan 5.3 software of the Cochrane Collaboration. The effect size was calculated as weighted mean differences (WMDs) and standardized mean difference (SMD) with 95\% confidence intervals (CIs). Summary estimates of the treatment effects were calculated using a random-effects model. Chi-squared and Higgins I2 statistics were used to assess the heterogeneity of the data. 


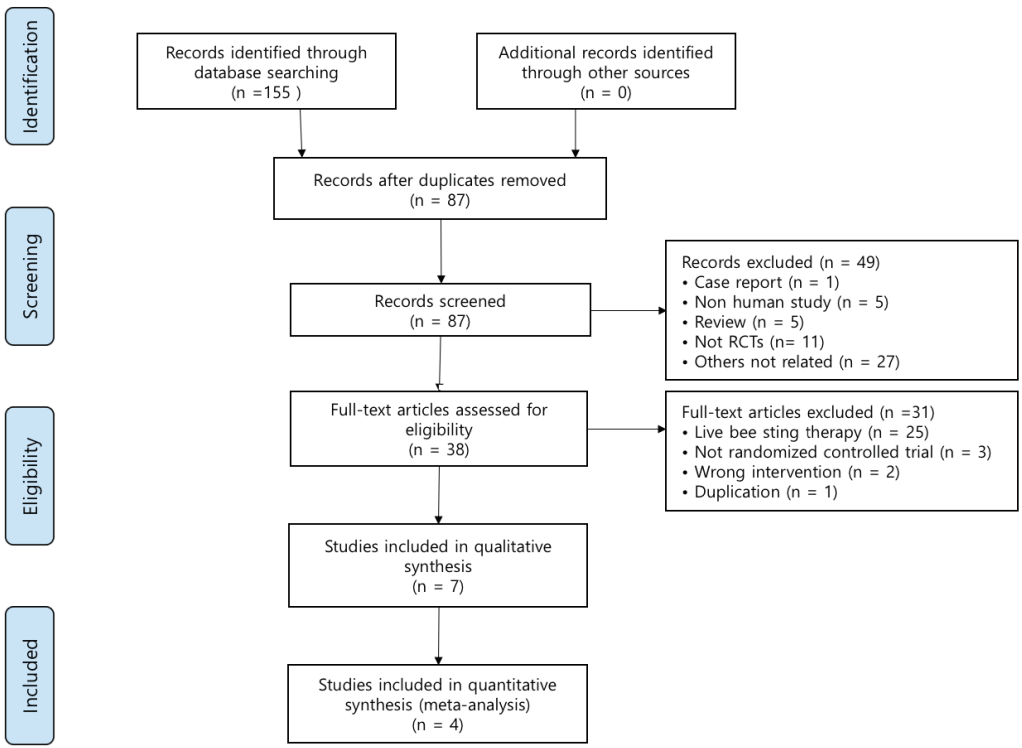

Figure 1 Flow chart of the study selection process.

Table 1 General characteristics of the included studies.

\begin{tabular}{|c|c|c|c|c|c|c|c|}
\hline $\begin{array}{l}\text { Author } \\
\text { (year) }\end{array}$ & $\begin{array}{l}\text { Types of } \\
\text { disease }\end{array}$ & $\begin{array}{l}\text { Participants } \\
\text { age } \\
\text { (mean } \pm \text { SD) }\end{array}$ & $\begin{array}{l}\text { Sample } \\
\text { size } \\
(\mathrm{N}= \\
\text { total) }\end{array}$ & $\begin{array}{l}\text { Intervention } \\
\text { group } \\
\text { (dilution ratio) }\end{array}$ & Control group & $\begin{array}{c}\text { Duration } \\
\text { (frequency / total } \\
\text { period) }\end{array}$ & Major Acupoints \\
\hline $\begin{array}{l}\text { Cho et al. } \\
\text { (2005) [14] }\end{array}$ & $\begin{array}{l}\text { Post-stroke } \\
\text { hemiplegic } \\
\text { shoulder pain }\end{array}$ & $\begin{array}{l}\text { A: } 58.55 \pm \\
15.07 \\
\text { B: } 61.50 \pm \\
10.98\end{array}$ & $\begin{array}{l}N=23 \\
A=11 \\
B=12\end{array}$ & $\begin{array}{l}\text { A: BVA + CT } \\
\text { (AT, PT, WM, } \\
\text { HM) }(1: 20,000)\end{array}$ & $\begin{array}{l}B: Z G+C T \\
(A T, P T, W M, \\
H M)\end{array}$ & $\begin{array}{l}3 \text { times a week } \\
\text { / } 2 \text { weeks }\end{array}$ & $\begin{array}{l}\text { LI15, TE14, GB21, } \\
\text { SI10 }\end{array}$ \\
\hline $\begin{array}{l}\text { Eom et al. } \\
\text { (2006) [15] }\end{array}$ & $\begin{array}{l}\text { Post-stroke } \\
\text { hemiplegic } \\
\text { shoulder pain }\end{array}$ & $\begin{array}{l}\text { A: } 69.2 \pm 9.6 \\
\text { B: } 67.3 \pm 8.9 \\
\text { C: } 67.7 \pm 15.0\end{array}$ & $\begin{array}{l}N=30 \\
A=10 \\
B=10 \\
C=10\end{array}$ & A: BVA $(1: 2,000)$ & $\begin{array}{l}\text { B: AT with BV } \\
\text { coating needle } \\
\text { C: AT }\end{array}$ & $\begin{array}{l}3 \text { times a week } \\
\text { / } 4 \text { weeks }\end{array}$ & $\begin{array}{l}\text { LI11, SI3, LI15, } \\
\text { UE12, SI10 }\end{array}$ \\
\hline $\begin{array}{l}\text { Ko et al. } \\
\text { (2007) [16] }\end{array}$ & $\begin{array}{l}\text { Shoulder pain } \\
\text { after stroke }\end{array}$ & $\begin{array}{l}\text { A: } 64.33 \pm 9.88 \\
\text { B: } 67.50 \pm 9.60\end{array}$ & $\begin{array}{l}N=46 \\
A=24 \\
B=22\end{array}$ & $\begin{array}{l}\text { A: BVA + CT (AT, } \\
\text { HM, MT, PT) } \\
(1: 10,000)\end{array}$ & $\begin{array}{l}\text { B: Saline } \\
\text { injection + CT } \\
\text { (AT, HM, MT, PT) }\end{array}$ & $\begin{array}{l}3 \text { times a week } \\
\text { / } 2 \text { weeks }\end{array}$ & LI15, TE14, GB21 \\
\hline $\begin{array}{l}\text { Koh et al. } \\
\text { (2013) [19] }\end{array}$ & $\begin{array}{l}\text { Adhesive } \\
\text { capsulitis }\end{array}$ & $\begin{array}{l}\text { A: } 54.95 \pm 6.79 \\
\text { B: } 56.18 \pm 6.70 \\
\text { C: } 55.13 \pm 7.01\end{array}$ & $\begin{array}{l}N=68 \\
A=22 \\
B=23 \\
C=23\end{array}$ & $\begin{array}{l}\text { A: BVA + PT } \\
(1: 10,000) \\
\text { B: BVA + PT } \\
(1: 30,000)\end{array}$ & $\begin{array}{l}\text { C: Saline } \\
\text { injection + PT }\end{array}$ & $\begin{array}{l}2 \text { times a week } \\
\text { / } 12 \text { weeks }\end{array}$ & $\begin{array}{l}\text { LI15, LI16, TE14, } \\
\text { GB21, SI11, } 5 \\
\text { additional points } \\
\text { around the } \\
\text { shoulder }\end{array}$ \\
\hline $\begin{array}{l}\text { Lee et al. } \\
\text { (2006) [17] }\end{array}$ & $\begin{array}{l}\text { Shoulder pain } \\
\text { patients in } \\
\text { stroke } \\
\text { sequelae }\end{array}$ & $\begin{array}{l}\text { A: } 62.45 \pm 9.2 \\
\text { B: } 68 \pm 10.4\end{array}$ & $\begin{array}{l}N=40 \\
A=20 \\
B=20\end{array}$ & $\begin{array}{l}A: B V A+C T(A T, \\
W M, H M, M T \\
P T)(1: 4,000 \text { and } \\
1: 10,000)\end{array}$ & $\begin{array}{l}\text { B: CT (AT, WM, } \\
\text { HM, MT, PT) }\end{array}$ & $\begin{array}{l}3 \text { times a week } \\
/ 3 \text { weeks }\end{array}$ & $\begin{array}{l}\text { LI15, TE14, GB21, } \\
\text { SI9, SI10, LI11, } \\
\text { SI11, additional } \\
\text { ashi points }\end{array}$ \\
\hline $\begin{array}{l}\text { Park et al. } \\
\text { (2011) [18] }\end{array}$ & $\begin{array}{l}\text { Post-stroke } \\
\text { hemiplegic } \\
\text { shoulder pain }\end{array}$ & $\begin{array}{l}\text { A: } 62.52 \pm \\
12.20 \\
B: 64.26 \pm \\
11.11\end{array}$ & $\begin{array}{l}N=40 \\
A=21 \\
B=19\end{array}$ & $\begin{array}{l}\mathrm{A}: \mathrm{BVA}+\mathrm{CT} \text { (AT, } \\
\mathrm{HM}, \mathrm{MT}, \mathrm{PT} \text { ) } \\
\text { (Not reported } \\
\text { dilution ratio) }\end{array}$ & $\begin{array}{l}\text { B: Saline } \\
\text { injection + CT } \\
\text { (AT, HM, MT, PT) }\end{array}$ & $\begin{array}{l}3 \text { times a week } \\
\text { / } 4 \text { weeks }\end{array}$ & $\begin{array}{l}\text { LI15, TE14, GB21, } \\
\text { SI10, additional } \\
\text { ashi points }\end{array}$ \\
\hline $\begin{array}{l}\text { Park et al. } \\
\text { (2014) [20] }\end{array}$ & $\begin{array}{l}\text { Adhesive } \\
\text { capsulitis }\end{array}$ & $\begin{array}{l}\text { A: } 55.4 \pm 6.8 \\
\text { B: } 52.8 \pm 7.3 \\
\text { C: } 56.4 \pm 7.9\end{array}$ & $\begin{array}{l}N=60 \\
A=20 \\
B=22 \\
C=18\end{array}$ & $\begin{array}{l}A: B V A+P T \\
(1: 10,000) \\
B: B V A+P T \\
(1: 30,000)\end{array}$ & $\begin{array}{l}\text { C: Saline } \\
\text { injection + PT }\end{array}$ & $\begin{array}{l}2 \text { times a week } \\
/ 2 \text { months } \\
\text { one-year follow up }\end{array}$ & $\begin{array}{l}\text { LI15, LI16, TE14, } \\
\text { GB21, SI11, } 5 \\
\text { additional points } \\
\text { around the } \\
\text { shoulder }\end{array}$ \\
\hline
\end{tabular}

BVA, bee venom acupuncture; AT, acupuncture therapy; PT, physiotherapy; ZG, Zingiberis Rhizoma acupuncture therapy; BV, bee venom; HM, herbal medicine; MT, moxibustion; WM, western medicine; $\mathrm{CT}$, conventional therapy. 


\section{Results}

\subsection{Study description}

From 11 electronic databases, 155 potentially relevant articles were retrieved. Among them, 148 articles were excluded. Seven studies [14-20] (Korean: $n=5$; English: $\mathrm{n}=2$ ) were included in the qualitative synthesis and four studies $[16,18-20]$ were included in the quantitative synthesis (meta-analysis) (Fig. 1). A total of 307 participants were included in these studies, 128 in the BVA group and 124 in the control group. Two $[19,20]$ of included studies assessed the effects of BVA on adhesive capsulitis and five [14-18] assessed the effects of BVA on post-stroke shoulder pain (Table 1). The duration of treatment varied from 2 to 12 weeks in the included studies. One study [20] was conducted one year follow up after 2 months of treatment.

\subsection{Characteristics of the bee venom intervention}

The participants were intramuscularly injected with bee venom using a syringe at various acupoints. Dried bee venom powder was diluted in saline at various ratios: 1:10000 in 3 studies [16, 19, 20], 1:20000 in one study [14], 1:2000 in one study [15], 1:4000 and 1:10000 in one study [17]. One study [18] did not report dilution rates. To summarize the acupoints were injected with bee venom, LI15 was used in all studies [14-20], TE14 and GB21 in 6 studies [14, 16-20], SI10 in 4 studies $[14,15,17,18]$, SI11 in 3 studies [17, 19, 20], LI16 in 2 studies [19, 20], LI11 in 2 studies [15, 17], SI9 in one study [17], SI3 in one study [15], UE12 in one study [15], and ashi points in two studies [17, 18] (Table 1).

\subsection{Characteristics of the control intervention}

In seven studies, control interventions were classified into four types. First, normal saline was used as control intervention in four studies [16, 18-20]. Two of them [19, $20]$ were given physiotherapy (PT), and the others $[16,18]$ were given $\mathrm{CT}$ such as classic acupuncture (AT), moxibustion, herbal medicine, PT. Secondly, AT was used in one study [15] as control intervention. Thirdly, Zingiberis Rhizoma herbal acupuncture therapy was used one study [14] as control intervention. In this study, all participants were treated with CT such as AT, herbal medicine, western medicine, PT. Fourthly, One study [17] did not provide any control intervention. In this study, all participants were treated with CT such as AT, herbal medicine, western medicine, moxibustion, PT (Table 1).

\subsection{Characteristics of outcome measures}

In a total of seven studies, VAS was used in six studies [1419]. In three of these studies [16-18], there were significant differences in the BVA group compared to control group and only one study [14] suggested no significant difference between the two groups. In addition, two studies $[15,19]$ did not report appropriate statistical data. Park et al. [20] used VRS to evaluate shoulder pain, but there was no significant difference between the two groups ( $p>0.05)$. PRS was used in the two studies $[16,18]$, in which there were significant differences between two groups $(\mathrm{p}<0.05)$. SPADI was used in two studies $[19,20]$, both of which showed significant differences between the two groups $(\mathrm{p}<0.05)$ (Table 2).

\subsection{Risk of bias in the included studies}

The risk of bias of included 7 studies was shown in Figure 2. All studies mentioned "randomization", but only 3 studies $[16,18,19]$ reported adequate methods of sequence generation - a table of random numbers [18], stratified sampling [16], and the bloc randomization method [19]. None of the trials mentioned whether they had adequate allocation concealment methods. Four studies $[16,18-20]$ were assessed to be low risk for blinding of participants and personnel. The remaining three studies $[14,15,17]$ compared BVA with AT, Zingiberis Rhizoma herbal acupuncture, and no control. Therefore, these studies were assessed to be at a high risk. Detection bias was low risk in four studies [16, 18-20], it was unclear in one study [14] because it did not mention the blinding of outcome assessment. Two studies $[15,17]$ were assessed to be at a high risk because blinding could affect the outcome assessment. Attrition bias was low risk in six studies [14-19], but it was high risk in one study [20] that did not report a complete set of baseline data. None of the trials reported information regarding the pre-registered protocol, therefore we assessed all trials to be unclear of reporting bias. We evaluated all of the studies as unclear of other bias because they had insufficient information to determine additional bias.

Figure 2 The summary of risk of bias.

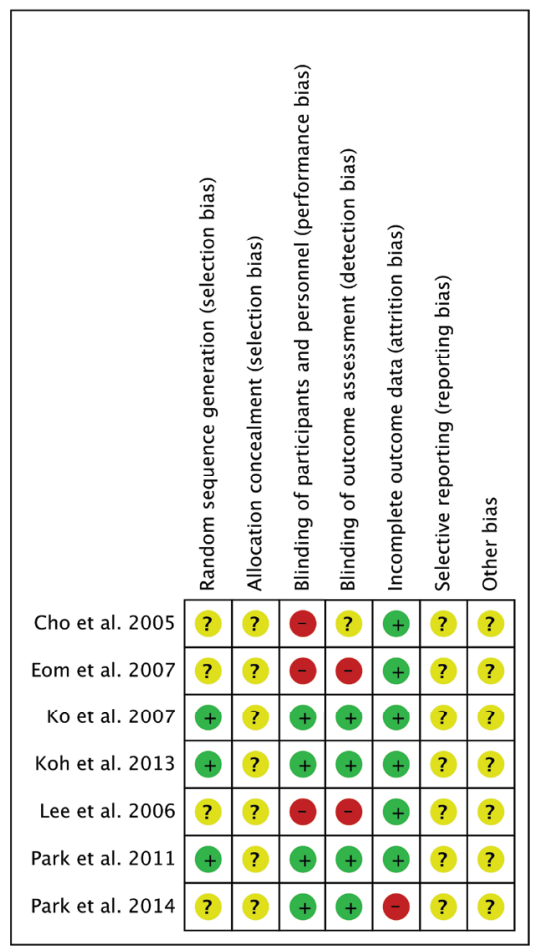




\subsection{Meta-analysis}

\subsubsection{Bee venom acupuncture versus saline injection}

3.6.1.1. Bee venom acupuncture plus $C T$ versus saline injection plus CT

Four of included trials [16, 18-20] were classified into several subgroups according to the type of control intervention used. Two of the RCTs $[16,18]$ that compared the effectiveness of BVA plus CT and saline injection plus CT reported significant differences in the VAS of shoulder pain. The cause of shoulder pain in both studies was poststroke shoulder pain. The meta-analysis suggested an effect in favor of BVA plus CT in VAS (SMD on 10-cm VAS, $1.25 ; 95 \% \mathrm{CI}=0.20$ to $2.29, \mathrm{p}=0.02, \mathrm{n}=86$; heterogenity, $\mathrm{p}$ $=0.03$, I $2=79 \%$; Fig. 3 [1.1.1]). Also, we found that shoulder pain was significantly lower for BVA plus CT than for saline plus CT, as assessed by the PRS (SMD, 0.58; 95\% CI $=0.15$ to $1.01, \mathrm{p}=0.009, \mathrm{n}=86$; heterogeneity, $\mathrm{p}=0.97, \mathrm{I} 2=0 \%$; Fig. 3 [1.1.2]). Overall, the result showed pain reduction was significantly greater for BVA than for saline injection (SMD, $0.89 ; 95 \% \mathrm{CI}=0.37$ to $1.41, \mathrm{p}=0.0007, \mathrm{n}=172$; heterogeneity, $\mathrm{p}=0.05$, I2 = 62\%; Fig. 3 ).

\subsubsection{Bee venom acupuncture plus PT versus saline injection plus PT}

In two studies $[19,20]$ on adhesive capsulitis disease, VAS (at night, rest, and motion), VRS (at night, rest, and motion), and SPADI were measured for BVA plus PT and saline plus PT. One trial [19] reported that there was no significant difference in VAS pain reduction at night (SMD on 10 -cm VAS, $0.34 ; 95 \% \mathrm{CI}=-0.24$ to $0.93, \mathrm{p}=0.25, \mathrm{n}=45$; Fig. 4 [2.1.1]), at rest (SMD on 10-cm VAS, $0.45 ; 95 \% \mathrm{CI}=-0.14$ to 1.05, $\mathrm{p}=0.13, \mathrm{n}=45$; Fig. 4 [2.1.2]), and at motion (SMD on 10 -cm VAS, $0.14 ; 95 \% \mathrm{CI}=-0.45$ to $0.72, \mathrm{p}=0.65, \mathrm{n}=45$; Fig. 4 [2.1.3]). Overall, the result showed pain reduction in VAS had no significant difference between BVA and saline injection (SMD, $0.31 ; 95 \% \mathrm{CI}=-0.03$ to $0.65, \mathrm{p}=0.07, \mathrm{n}=$ 135; heterogeneity, $\mathrm{p}=0.75$, I2 = 0\%; Fig. 4).

The other trial [20] reported that there was no significant difference in VRS of pain reduction at night (SMD, 0.23; $95 \% \mathrm{CI}=-0.41$ to $0.87, \mathrm{p}=0.48, \mathrm{n}=38$; Fig. 5 [2.2.1]), at rest (SMD, $-0.04 ; 95 \% \mathrm{CI}=-0.68$ to $0.59, \mathrm{p}=0.90, \mathrm{n}=38$; Fig. 5 [2.2.2]), and at motion (SMD, $0.12 ; 95 \% \mathrm{CI}=-0.52$ to $0.76, \mathrm{p}$ $=0.71, \mathrm{n}=38$; Fig. 5 [2.2.3]). Overall, the result showed pain reduction in VRS had no significant difference between

Figure 3 Forest plot of shoulder pain in BVA plus conventional therapy versus saline injection plus conventional therapy. BVA, bee venom acupuncture.

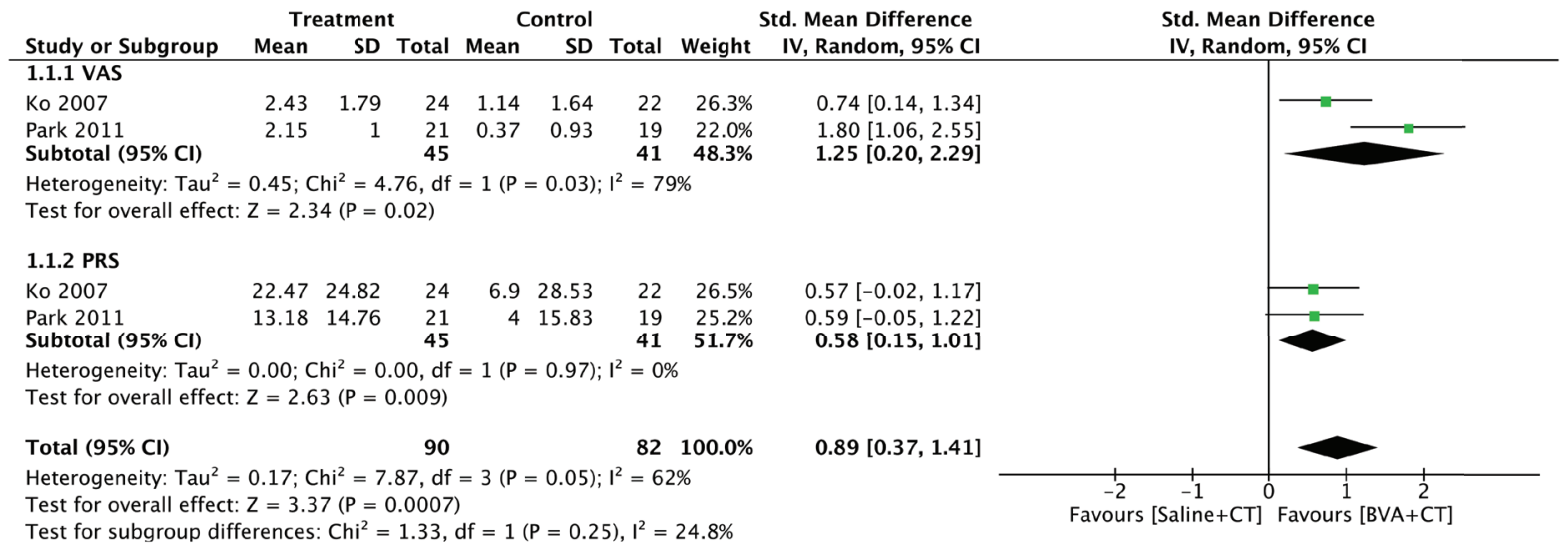

Figure 4 Forest plot of VAS in BVA plus physiotherapy versus saline injection plus physiotherapy. VAS, visual analog scale; BVA, bee venom acupuncture.

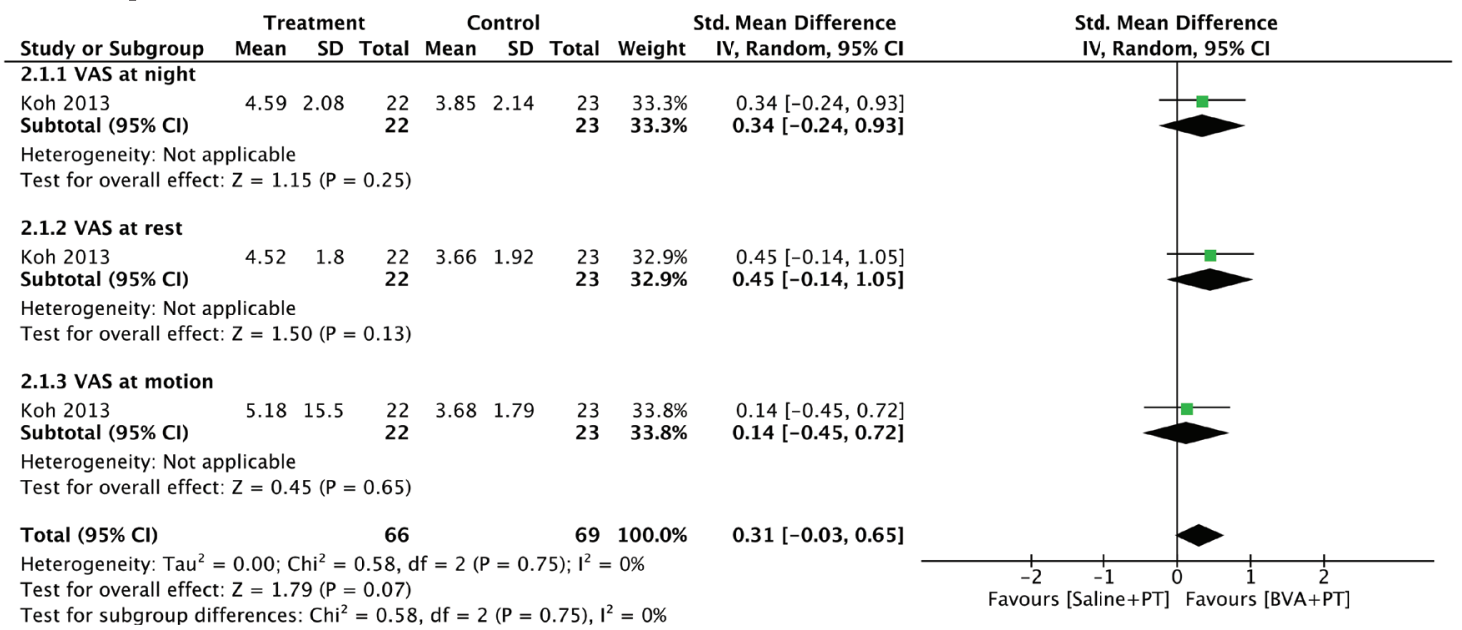


Figure 5 Forest plot of VRS in BVA plus physiotherapy versus saline injection plus physiotherapy. VRS, verbal rating scale; BVA, bee venom acupuncture.

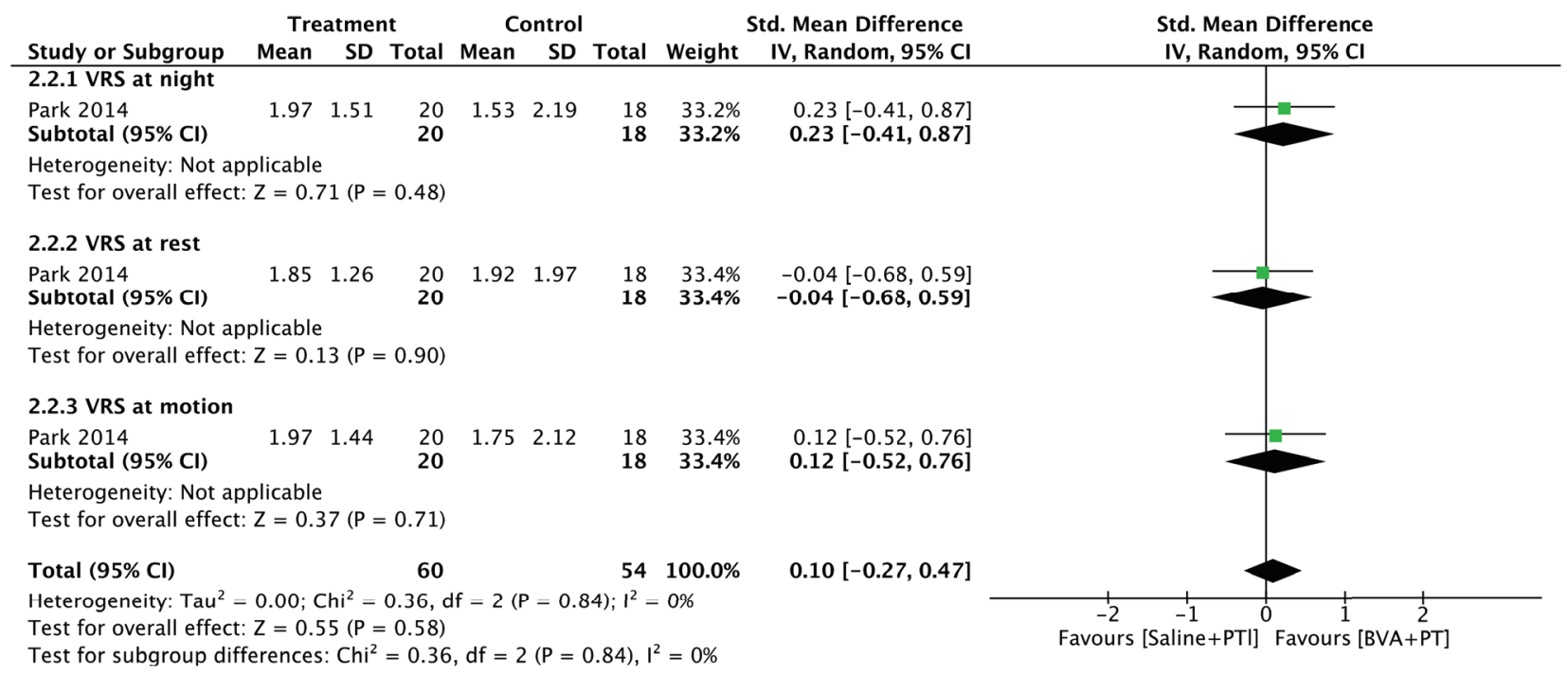

Figure 6 Forest plot of SPADI in BVA plus physiotherapy versus saline injection plus physiotherapy. SPADI, shoulder pain and disability index; BVA, bee venom acupuncture.

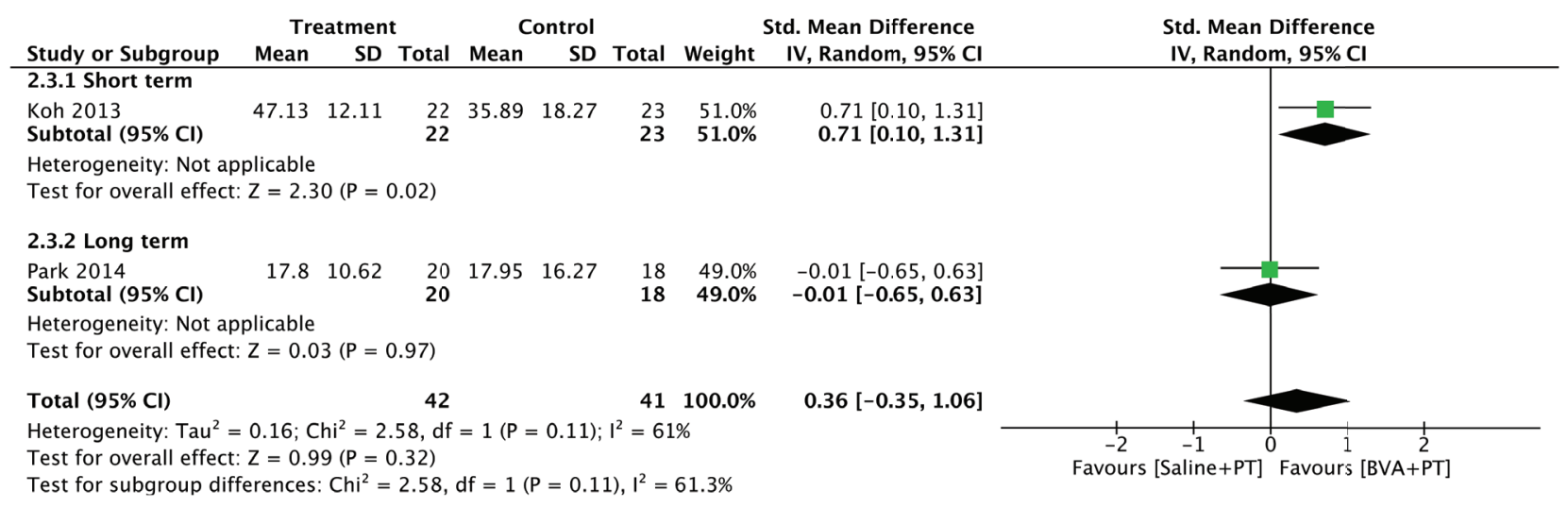

BVA and saline injection (SMD, $0.10 ; 95 \% \mathrm{CI}=-0.27$ to 0.47 , $\mathrm{p}=0.58, \mathrm{n}=114$; heterogeneity, $\mathrm{p}=0.84, \mathrm{I} 2=0 \%$; Fig. 5).

In 12-week short-term observations [19], BVA group showed significantly better outcomes in SPADI than the control group $(\mathrm{SMD}=0.71 ; 95 \% \mathrm{CI}=0.10$ to $1.31, \mathrm{p}=0.02$; $\mathrm{n}=45$; Fig. 6 [2.3.1]). In a one-year long-term observation [20], SPADI had no significant difference between the two groups $(\mathrm{SMD}=-0.01 ; 95 \% \mathrm{CI}=-0.65$ to $0.63, \mathrm{p}=0.97, \mathrm{n}=$ 38; Fig. 6 [2.3.2]). Overall, the result showed pain reduction in SPADI had no significant difference between BVA and saline injection (SMD, 0.36 ; 95\% CI $=-0.35$ to $1.06, \mathrm{p}=0.32$, $\mathrm{n}=83$; heterogeneity, $\mathrm{p}=0.11, \mathrm{I} 2=61 \%$; Fig. 6).

\subsection{Adverse events}

Two $[16,19]$ of the seven studies reported adverse events. Both studies used saline injection as the control intervention. One study [16] included pruritus ( 8 in the BVA group and 2 in the control group), burning sensation (3 in the
BVA group and 1 in the control group), and pain (2 in the BVA group and 3 in the control group). All of these adverse events were Mueller Grade 0 , and symptoms were relieved after using ice packs. In the other study [19], among the 45 patients in the BV1 and BV2 groups who received BVA, 30 patients experienced slight pruritus, local swelling, and or redness (under $20 \mathrm{~mm}$ in diameter), which were Mueller Grade 0. One patient showed mild, generalized swelling and aching (in BV1 group), which were classified as Mueller Grade 1 reactions, and 3 patients showed slight redness and pruritus (in control group). The rest five studies [14, $15,17,18,20$ ] did not mention any information about adverse events (Table 2).

\section{Discussion}

This is a systematic review and meta-analysis to investigate the efficacy and safety of BVA for shoulder pain. The results of the systematic reviews and meta-analyses 
Table 2 The outcome of included studies.

\begin{tabular}{|c|c|c|c|}
\hline $\begin{array}{l}\text { Author } \\
\text { (year) }\end{array}$ & Outcome & Results & Adverse events \\
\hline $\begin{array}{l}\text { Cho et al. } \\
(2005)[14]\end{array}$ & $\begin{array}{l}\text { 1. MMT } \\
\text { 2. VAS } \\
\text { 3. PROM }\end{array}$ & $\begin{array}{l}\text { 1. No differences between the two groups }(p>0.05) \text {. } \\
\text { 2. No differences between the two groups }(p>0.05) \text {. } \\
\text { 3. In PROM, ZG had some effectiveness on abduction and flexion, but BV had } \\
\text { effectiveness on all movement }\end{array}$ & Not reported \\
\hline $\begin{array}{l}\text { Eom et al. } \\
\text { (2006) [15] }\end{array}$ & $\begin{array}{l}\text { 1. VAS } \\
\text { 2. FMMA } \\
\text { 3. PROM } \\
\text { 4. Modified } \\
\text { ashworth } \\
\text { scale }\end{array}$ & $\begin{array}{l}\text { 1. Ratio of VAS showed significant decrease in BVA and BV coating needle groups } \\
\text { compared to the AT group }(p<0.05) \\
\text { 2. FMMA showed significant increase in all groups }(p<0.05) \text {, No differences } \\
\text { between the three groups. }(p>0.05) \\
\text { 3. PROM showed significant increase in all groups }(p<0.05) \text {, No differences } \\
\text { between the three groups. }(p>0.05) \\
\text { 4. No differences between the three groups. }(p>0.05)\end{array}$ & Not reported \\
\hline $\begin{array}{l}\text { Ko et al. } \\
\text { (2007) [16] }\end{array}$ & $\begin{array}{l}\text { 1. VAS, PRS } \\
\text { 2. FMMA } \\
\text { 3. PROM }\end{array}$ & $\begin{array}{l}\text { 1. VAS: A }>\text { B }(p=0.022), \text { PRS: A }>\text { B }(p=0.034) \\
\text { 2. No differences between the two groups. }(p>0.05) \\
\text { 3. No differences between the two groups. }(p>0.05)\end{array}$ & $\begin{array}{l}\text { 1. Pruritus: } A(n=8), B \\
(n=2) \\
\text { 2. Burning sensation: } A \\
(n=3), B(n=1) \\
\text { 3. Pain: } A(n=2), B(n= \\
\text { 3) }\end{array}$ \\
\hline $\begin{array}{l}\text { Koh et al. } \\
\text { (2013) [19] }\end{array}$ & $\begin{array}{l}\text { 1. SPADI } \\
\text { 2. VAS } \\
\text { 3. PROM }\end{array}$ & $\begin{array}{l}\text { 1. A }>C(p<0.05 \text {, at } 8 \text { and } 12 \text { weeks), No differences between the A and B groups. } \\
(p>0.05) \\
\text { 2. A }>C(p<0.05 \text {, at } 8 \text { weeks (at rest) and } 12 \text { weeks (during motion) }) \text {, No } \\
\text { differences between the A and B groups. ( } p>0.05) \\
\text { 3. No differences between the three groups. }(p>0.05)\end{array}$ & $\begin{array}{l}\text { 1. Slight pruritus, local } \\
\text { swelling, redness } \\
\text { (Mueller Grade 0): A } \\
\text { and B }(n=30) \\
\text { 2. Mild, generalized } \\
\text { swelling, aching } \\
\text { (Mueller Grade 1): A ( } \\
=1 \text { ). } \\
\text { 3. Slight redness and } \\
\text { pruritus: } C(n=3) \\
\text { 4. No SAEs. }\end{array}$ \\
\hline $\begin{array}{l}\text { Lee et al. } \\
\text { (2006) [17] }\end{array}$ & $\begin{array}{l}\text { 1. VAS } \\
\text { 2. PROM }\end{array}$ & $\begin{array}{l}\text { 1. } \mathrm{A}>\mathrm{B}(p<0.05) \\
\text { 2. No differences between the two groups. }(p>0.05)\end{array}$ & Not reported \\
\hline $\begin{array}{l}\text { Park et al. } \\
\text { (2011) [18] }\end{array}$ & $\begin{array}{l}\text { 1. VAS, PRS } \\
\text { 2. PROM } \\
\text { 3. FMMA }\end{array}$ & $\begin{array}{l}\text { 1. VAS: A }>\text { B }(p<0.05) \text {; PRS: A }>\text { B }(p<0.05 \text {, after } 4 \text { weeks treatment) } \\
\text { 2. No differences between the two groups. }(p>0.05) \\
\text { 3. No differences between the two groups. }(p>0.05)\end{array}$ & Not reported \\
\hline $\begin{array}{l}\text { Park et al. } \\
\text { (2014) [20] }\end{array}$ & $\begin{array}{l}\text { 1. SPADI } \\
\text { 2. VRS }\end{array}$ & $\begin{array}{l}\text { 1. A }>C(p=0.043) \\
\text { 2. No differences between the three groups. }(p>0.05)\end{array}$ & Not reported \\
\hline
\end{tabular}

MMT, manual muscle test; VAS, visual analog scale; PROM, passive range of motion; FMMA, fugl-meyer motor assessment; PRS, pain rating score; SPADI, shoulder pain, VRS, verbal rating scale.

showed the benefit of BVA on shoulder pain. However, there were insufficient information, small sample size, and small RCTs to draw firm conclusions.

There has been one systematic review and meta-analysis of RCTs concerning BVA efficacy in reducing shoulder pain. Lim et al. [8] reviewed and meta-analyzed the effectiveness of BVA in alleviating post-stroke shoulder pain. However, this review was limited to shoulder pain after the occurrence of a stroke, so it failed to show the efficacy of BVA in treating shoulder pain by other causes.

Pharmacopuncture is a new acupuncture treatment method with the combination of herbal medicine and acupuncture. BVA is one of the most common pharmacopuncture, which has been used in clinic for many years. BVA is to inject diluted bee venom into an acupoint using a syringe, and treat a patient through both the pharmacologic effects and acupuncture effect. Previous studies have shown that bee venom has many effects such as anti-inflammatory, anti-cancer, and regulating immunity and so on $[21,22]$. Based on these pharmacological effects, BVA is often used to treat various diseases such as rheumatoid arthritis, low back pain, and cancer [23-25]. In vivo experiments, BVA showed a potential analgesic effect [26]. Choi et al. [27] observed that BVA has significant analgesic ef- 
fects in rats with paclitaxel-induced neuropathic pain.

The diseases causing shoulder pain in this review are adhesive capsulitis in two studies and post-stroke in five studies. Adhesive capsulitis usually refers to the inflammation of articular capsule, characterized by a painful stiff shoulder, and is one of many conditions that progressively limit shoulder motion $[28,29]$. Shoulder pain is one of the most common complications following stroke and may delay recovery of stroke [30]. Shoulder pain is usually experienced during rest or exercise, restricting shoulder mobility and affecting quality of life. Regardless of the cause of the shoulder pain, there is no universally effective treatment for shoulder pain, and most of them are accompanied by varying degrees of side effects. Therefore, it is necessary to find an effective and safe complementary and alternative therapy.

Two $[16,18]$ of the included studies compared the effectiveness of BVA plus CT with saline injection plus CT for treating shoulder pain. The meta-analysis suggested an effect in favor of BVA plus CT in VAS and PRS. Two [19, 20] of the included studies compared BVA plus PT with saline injection plus PT. VAS and VRS were used to measure pain at night, rest, and motion, respectively. Meta-analysis showed that there was no significant difference in VAS and VRS between the two groups. In addition, SPADI was used to measure the quality of life. During the 12-week shortterm observation [19], there was a significant difference in SPADI scores between the BVA and control groups. However, during the long-term follow-up [20], there was no significant difference between BVA and control groups.

Based on currently available evidence, our meta-analysis found that BVA was an effective option for shoulder pain relief. This kind of therapy could benefit shoulder pain, especially as an adjunctive therapy. In Korea, BVA therapy is already widely used for shoulder pain and is becoming an important treatment option.

This systematic review has several limitations. First of all, the included studies exhibited various degrees of bias susceptibility. Among the included 7 studies, only 3 studies $[16,18,19]$ reported an adequate method of random sequence generation. Allocation concealment was not described in the included 7 studies. 3 studies $[14,16,17]$ had a high risk in blinding of participants and personnel. Secondly, all included studies were conducted in Korea. Although extensive research and practice has been conducted in Korea, this might indicate a publication bias and limit the external generalization of the evidence. Thirdly, the sample size of the included studies were small and calculation methods were not reported. This means that statistical power of each study is unknown even though pooled estimate indicated significant effect of BVA. Fourthly, since BVA administration is likely to cause discomfort, some participants who had previously experienced BVA treatment may have known what they were received with. This issue can interfere the patient blinding. Fifthly, only 2 of the 7 studies $[16,19]$ reported adverse events, while the other 5 studies $[14,15,17,18,20]$ did not mention adverse events. In some case reports, severe adverse events after BVA treatment have been reported, such as severe ulnar nerve injury and immune thrombocytopenia [31, 32]. Although no severe adverse events were reported in this review, the evidence was limited. Finally, this review only included studies published in journals except for dissertation papers and conference papers. Thus, a global and complete summary of all the evidence may not have been gathered. Future researchers are encouraged to register the protocols of clinical trials to ensure the research can be conducted according to the pre-defined protocol. Furthermore, it is necessary to calculate the appropriate sample size for statistical power, frequency, duration of treatment, and ideal follow-up. Also, appropriate study design, such as adequate randomization methods or double blinding, must be developed.

\section{Conclusion}

The results of this systematic review and meta-analysis suggest that BVA might be beneficial as an adjuvant treatment for shoulder pain. However, considering that the total number of included RCTs and sample size were too small, and most of the studies included in the review were assessed as a high methodological risk, so definitive conclusions cannot be drawn. In the future, more large-scale, rigorous RCTs should be conducted.

\section{Acknowledgment}

This study was supported by Wonkwang University in 2019.

\section{Conflict of interest}

The authors declare that there are no conflicts of interest.

\section{Appendix 1. Search strategy}

\author{
1. MEDLINE-Pubmed \\ \#1 bee venoms [MeSH Terms] \\ \#2 apitoxin \\ \#3 apitherapy \\ \#4 apipuncture \\ \#5 bee venom therapy \\ \#6 bee venom acupuncture \\ \#7 bee sting \\ \#8 wasp venom \\ \#9 \# 1 OR \#2 OR \#3 OR \#4 OR \#5 OR \#6 \#7 OR \#8 \\ \#10 shoulder pain [MeSH Terms] \\ \#11 bursitis [MeSH Terms] \\ \#12 shoulder impingement syndrome \\ \#13 rotator cuff \\ \#14 adhesive capsulitis \\ \#15 tendinitis \\ \#16 tendonitis \\ \#17 frozen shoulder \\ \#18 shoulder* \\ \#19 \#10 OR \#11 OR \#12 OR \#13 OR \#14 OR \#15 OR \#16 OR \\ \#17 OR \#18 \\ \#20 \#9 AND \#19
}

\section{EMBASE \\ \#1 'bee venoms'/exp \\ \#2 apitoxin}


\#3 apitherapy

\#4 apipuncture

\#5 bee venom therapy

\#6 bee venom acupuncture

\#7 bee sting

\#8 wasp venom

\#9 \#1 OR \#2 OR \#3 OR \#4 OR \#5 OR \#6 \#7 OR \#8

\#10 'shoulder pain'/exp

\#11 'Bursitis'/exp

\#12 shoulder impingement syndrome

\#13 rotator cuff

\#14 adhesive capsulitis

\#15 tendinitis

\#16 tendonitis

\#17 frozen shoulder

\#18 shoulder*

\#19 \#10 OR \#11 OR \#12 OR \#13 OR \#14 OR \#15 OR \#16 OR

\#17 OR \#18

\#20 \#9 AND \#19

3. Cochrane Central Register of Controlled Trials

\#1 MeSH descriptor: [Bee Venoms] explode all trees

\#2 apitoxin

\#3 apitherapy

\#4 apipuncture

\#5 bee venom therapy

\#6 bee venom acupuncture

\#7 bee sting

\#8 wasp venom

\#9 \#1 OR \#2 OR \#3 OR \#4 OR \#5 OR \#6 \#7 OR \#8

\#10 MeSH descriptor: [Shoulder pain] explode all trees

\#11 MeSH descriptor: [Bursitis] explode all trees

\#12 shoulder impingement syndrome

\#13 rotator cuff

\#14 adhesive capsulitis

\#15 tendinitis

\#16 tendonitis

\#17 frozen shoulder

\#18 shoulder*

\#19 \#10 OR \#11 OR \#12 OR \#13 OR \#14 OR \#15 OR \#16 OR

\#17 OR \#18

\#20 \#9 AND \#19

4. CiNii

(bee venom OR apitoxin OR apitherapy OR apipuncture OR bee venom therapy OR bee venom acupuncture OR bee sting OR wasp venom) \& (shoulder OR shulder pain OR Bursitis OR shoulder impingement OR rotator cuff OR adhesive capsulitis OR tendinitis OR tendonitis OR frozen shoulder)

\section{CNKI}

$\mathrm{SU}=($ '蜂针 '+ '蜂针穴位治疗 '+ '蜂针穴位注射 '+ '蜂毒 '+' 蜂毒穴位治疗'+'蜂毒穴位注射') AND SU=('肩痛'+'肩 周炎 '+'肩关节周围炎 '+'肩手综合征'+'颈肩痛'+'颈肩 综合症 '+'冻结肩 '+'五十肩')

6. Wanfang

主题: ("蜂针"+"蜂针穴位治疗"+"蜂针穴位注射"+"蜂 毒"+"蜂毒穴位治疗"+"蜂毒穴位注射") AND 主题:("肩
痛"+"肩周炎"+"肩关节周围炎"+"肩手综合征"+"颈肩综 合症"+"冻结肩"+ "五十肩")

7. VIP

$M=($ 蜂针+蜂针穴位治疗+蜂针穴位注射+蜂毒+蜂毒穴位治 疗+蜂毒穴位注射 $)^{\star} M=($ 肩痛+肩周炎+肩关节周围炎+肩手 综合征+颈肩综合症+冻结肩+五十肩)

8. Kmbase

(((([ALL=오십견 $]$ OR $[\mathrm{ALL}=$ 유착성관절낭염 $])$ OR [ALL= 견관절주위염]) OR [ALL=동결견]) OR [ALL=어깨통증]) AND (( ( [ALL=벌침 $]$ OR $[\mathrm{ALL}=$ 벌독 $]) \quad O R \quad[\mathrm{ALL}=$ 봉독약 침]) $\mathrm{OR}[\mathrm{ALL}=$ 봉약침]) $\mathrm{OR}[\mathrm{ALL}=$ 봉침])

9. RISS

(오십견 $\mathrm{OR}$ 유착성 관절낭염 $\mathrm{OR}$ 견관절 주위염 $\mathrm{OR}$ 동결 견 $\mathrm{OR}$ 어깨통증) $\mathrm{AND}$ (벌침 $\mathrm{OR}$ 벌독 $\mathrm{OR}$ 봉독 $\mathrm{OR}$ 봉약 침 $\mathrm{OR}$ 봉침)

10. OASIS

(오십견 $\mathrm{OR}$ 유착성 관절낭염 $\mathrm{OR}$ 견관절 주위염 $\mathrm{OR}$ 동결 견 $\mathrm{OR}$ 어깨통증) $\mathrm{AND}$ (벌침 $\mathrm{OR}$ 벌독 $\mathrm{OR}$ 봉독 $\mathrm{OR}$ 봉약 침 $\mathrm{OR}$ 봉침)

11. NDSL

(오십견 $\mathrm{OR}$ 유착성 관절낭염 $\mathrm{OR}$ 견관절 주위염 $\mathrm{OR}$ 동결 견 $\mathrm{OR}$ 어깨통증) $\mathrm{AND}$ (벌침 $\mathrm{OR}$ 벌독 $\mathrm{OR}$ 봉독 $\mathrm{OR}$ 봉약 침 $\mathrm{OR}$ 봉침)

\section{ORCID}

Jong Cheon Joo. http://orcid.org/0000-0002-4404-0309 Yung Sun Song. http://orcid.org/0000-0002-6318-0585 Park Soo Jung. http://orcid.org/0000-0001-8191-4290 Jong Ha Lee. http://orcid.org/0000-0002-2434-8429 Lei Shen. http://orcid.org/0000-0003-4102-2401

\section{Reference}

1. Kim YS, Jun H, Chae Y, Park HJ, Kim BH, Chang IM, et al. The practice of Korean medicine: an overview of clinical trials in acupuncture. Evid Based Complement Alternat Med. 2005;2(3):325-52.

2. Lee WR, Pak SC, Park KK. The protective effect of bee venom on fibrosis causing inflammatory diseases. Toxins (Basel). 2015;7(11):4758-72.

3. Chen J. Spinal processing of bee venom-induced pain and hyperalgesia. Sheng li xue bao. 2008;60(5):645-652.

4. Koburova KL, Michailova SG, Shkenderov SV. Further investigation on the antiinflammatory properties of adolapin--bee venom polypeptide. Acta Physiol Pharmacol Bulg. 1985;11(2):50-5.

5. Park HJ, Son DJ, Lee CW, Choi MS, Lee US, Song HS, et al. Melittin inhibits inflammatory target gene expression and mediator generation via interaction with IkappaB kinase. Biochem Pharmacol. 2007;73(2):237-47.

6. Urwin M, Symmons D, Allison T, Brammah T, Busby $\mathrm{H}$, Roxby M, et al. Estimating the burden of musculo- 
skeletal disorders in the community: the comparative prevalence of symptoms at different anatomical sites, and the relation to social deprivation. Ann Rheum Dis. 1998;57(11):649-55.

7. van der Windt DA, Koes BW, Boeke AJ, Deville W, De Jong BA, Bouter LM. Shoulder disorders in general practice: prognostic indicators of outcome. Br J Gen Pract. 1996;46(410):519-23.

8. Lim SM, Lee SH. Effectiveness of bee venom acupuncture in alleviating post-stroke shoulder pain: a systematic review and meta-analysis. J Integr Med. 2015;13(4):241-7.

9. Lee MS, Pittler MH, Shin BC, Kong JC, Ernst E. Bee venom acupuncture for musculoskeletal pain: a review. J Pain. 2008;9(4):289-97.

10. Chul K, Changhyo K, Il CS. Clinical Value of a New Self Assessment Method of Pain. J Korean Acad Rehabil Med. 1998;22(2):304-11.

11. Williamson A, Hoggart B. Pain: a review of three commonly used pain rating scales. J Clin Nurs. 2005;14(7):798-804.

12. Roach KE, Budiman-Mak E, Songsiridej N, Lertratanakul Y. Development of a shoulder pain and disability index. Arthritis Care Res. 1991;4(4):143-9.

13. Higgins JPT, Green S, eds. Cochrane Handbook for Systematic Reviews of Interventions version 5.1.0 [updated March 2011]. London, England; The Cochrane Collaboration; 2011. Available from: www. chochrane-handbook.org.

14. Cho SW, Go KH, Nam JH, Kim MS, Lee SY, Lee IS. The Effectiveness of Zingiberis Rhizoma Herbal Acupuncture Therapy and Bee Venom Herbal Acupuncture Therapy on the Poststroke Hemiplegic Shoulder Pain. J Orient Rehabi Med. 2005;15(4):77-87.

15. Eom JY, Won SH, Kwon KR, Lee HS. Comparative study of Acupuncture, Bee Venom Acupuncture and Bee Venom Herbal Acupuncture on the treatment of Poststroke Hemiplegic Shoulder Pain. J korean Pharmacopuncture institute. 2006;9(1):139-54.

16. Ko CN, Min IK, Park SW, Jung WS, Moon SK, Park JM. Effectiveness of Bee Venom Acupuncture on Shoulder Pain after Stroke. J Korean Oriental Med. 2007;28(1):1124.

17. Lee DY, Yeom SC, Kim DH, Kim DJ, Lee GM. A Clinical Study of Bee Venom Acupuncture Therapy on Shoulder Pain Patients in Stroke Sequelae. J Korean Acupunct Moxib Soc. 2006;23(4):69-80.

18. Park JA, Lee CH, Kwon KS, Lee KA, Jang KJ. The Effects of Sweet Bee Venom Pharmacopuncture on the Poststroke Hemiplegic Shoulder Pain. J Korean Acupunct Moxib Soc. 2011;28(4):37-47.

19. Koh PS, Seo BK, Cho NS, Park HS, Park DS, Baek YH. Clinical effectiveness of bee venom acupuncture and physiotherapy in the treatment of adhesive capsulitis: a randomized controlled trial. J Shoulder Elbow Surg. 2013;22(8):1053-62.

20. Park YC, Koh PS, Seo BK, Lee JW, Cho NS, Park HS, et al. Long-term effectiveness of bee venom acupuncture and physiotherapy in the treatment of adhesive capsulitis: A one-year follow-up analysis of a previous randomized controlled trial. J Altern Complement Med.
2014;20(12):919-24.

21. Son DJ, Lee JW, Lee YH, Song HS, Lee CK, Hong JT. Therapeutic application of anti-arthritis, pain-releasing, and anti-cancer effects of bee venom and its constituent compounds. Pharmacol Ther. 2007;115(2):24670.

22. Lee MJ, Jang M, Choi J, Lee G, Min HJ, Chung WS, et al. Bee Venom Acupuncture Alleviates Experimental Autoimmune Encephalomyelitis by Upregulating Regulatory T Cells and Suppressing Th1 and Th17 Responses. Mol Neurobiol. 2016;53(3):1419-45.

23. Jung GB, Huh JE, Lee HJ, Kim D, Lee GJ, Park HK, et al. Anti-cancer effect of bee venom on human MDAMB-231 breast cancer cells using Raman spectroscopy. Biomed Opt Express. 2018;9(11):5703-18.

24. Seo BK, Han K, Kwon O, Jo DJ, Lee JH. Efficacy of Bee Venom Acupuncture for Chronic Low Back Pain: A Randomized, Double-Blinded, Sham-Controlled Trial. Toxins (Basel). 2017;9(11).

25. Lee JA, Son MJ, Choi J, Jun JH, Kim JI, Lee MS. Bee venom acupuncture for rheumatoid arthritis: a systematic review of randomised clinical trials. BMJ Open. 2014;4(11):e006140.

26. Lee JD, Park HJ, Chae Y, Lim S. An Overview of Bee Venom Acupuncture in the Treatment of Arthritis. Evid Based Complement Alternat Med. 2005;2(1):79-84.

27. Choi J, Jeon C, Lee JH, Jang JU, Quan FS, Lee K, et al. Suppressive Effects of Bee Venom Acupuncture on Paclitaxel-Induced Neuropathic Pain in Rats: Mediation by Spinal alpha(2)-Adrenergic Receptor. Toxins (Basel). 2017;9(11).

28. Neviaser AS, Neviaser RJ. Adhesive capsulitis of the shoulder. J Am Acad Orthop Surg. 2011;19(9):536-42.

29. Wang W, Shi M, Zhou C, Shi Z, Cai X, Lin T, et al. Effectiveness of corticosteroid injections in adhesive capsulitis of shoulder: A meta-analysis. Medicine (Baltimore). 2017;96(28):e7529.

30. McLean DE. Medical complications experienced by a cohort of stroke survivors during inpatient, tertiary-level stroke rehabilitation. Arch Phys Med Rehabil. 2004;85(3):466-9.

31. Park JS, Park YG, Jang CH, Cho YN, Park JH. Severe Ulnar Nerve Injury After Bee Venom Acupuncture at a Traditional Korean Medicine Clinic: A Case Report. Ann Rehabil Med. 2017;41(3):483-7.

32. Abdulsalam MA, Ebrahim BE, Abdulsalam AJ. Immune thrombocytopenia after bee venom therapy: a case report. BMC Complement Altern Med. 2016;16:107. 